p-ISSN : 1979-0414(print)

e-ISSN : 2621-6256 (online)

http://journal.stekom.ac.id/index.php/pixel

\title{
ANIMASI 2D MEDIA PEMBELAJARAN JARINGAN ORGAN TUBUH MANUSIA BERBASIS MOBILE
}

\author{
Nur Budi Nugraha ${ }^{1 *}$, Soni fajar Mahmud ${ }^{2)}$ \\ ${ }^{1)}$ Program Studi Teknik Informatika, Sekolah Tinggi Teknologi Dumai \\ Jl. Utama Karya Bukit Batrem II Dumai, Riau 28815 \\ 'Program Studi Teknik Industri, Sekolah Tinggi Teknologi Dumai \\ Jl. Utama Karya Bukit Batrem II Dumai, Riau 28815 \\ Email : nurbudinugroho87@gmail.com
}

\begin{abstract}
Abstrak
Learning is a process of communication between students, teachers and teaching materials. The delivery of learning messages from teachers to students is currently still using props in the form of books. This makes students less interested and feel bored when absorbing lessons, so that it gives the effect of being lazy to learn. This study designed mobile based $2 D$ animation as an attractive learning medium for learning materials for human organs based on mobile android. This study uses the waterfall method in conducting research which includes the stages of planning, analysis, design, implementation and testing. Based on the research results, this $2 D$ animation learning media makes it easy for students to study material about human organs that cannot be seen directly. This animation has several elements such as text, audio, video and animated images so that it attracts students' attention to feel happy in learning compared to conventional ways.
\end{abstract}

Kata kunci-learning, human organ, 2D animation, mobile based

\section{Pendahuluan}

Perkembangan zaman dan era globalisasi memberikan tantangan tersendiri bagi lulusan ilmu pendidikan untuk menciptakan sistem pembelajaran yang dapat meningkatkan mutu pendidikan yang lebih baik [1]. Kebanyakan pola pendidikan di indonesia adalah menggunakan sistem konvensional dimana guru memberikan materi menggunakan buku pembelajaran [2]. Sehingga menjadi tantangan tersendiri bagi pendidik dalam menyampaikan materi kepada siswanya agar siswa tidak monoton dan bosan dalam kegiatan belajar di kelas [3]. Tidak heran banyak pendidik yang semakin ketinggalan mendapatkan informasi dibandingkan dengan siswanya. Hal itu disebabkan karena semakin cepat dan mudahnya informasi yang didapatkan oleh siswa tanpa harus menunggu pembelajaran disekolah karena siswa bisa mengakses informasinya melalui smartphone mereka [4].

Pada masa sekarang hampir semua orang memiliki smartphone karena mudahnya mendapatkan barang tersebut, selain itu juga dilengkapi dengan fitur fitur menarik serta cara penggunaannya yang lebih praktis dan efisien sehingga dapat membantu dalam proses belajar siswa diluar jam sekolah [5]. Kemudahan berinternet membuat siswa dan guru menemukan informasi menarik mengenai materi pembelajaran yang tidak didapatkan dari buku pelajaran [6][7]. Bentuk smartphone yang kecil dan mudah digunakan membuat siswa lebih tertarik mengggunakannya untuk mencari informasi pembelajaran tanpa harus terpaku pada buku [8]. Maka dapat dikatakan bahwa teknologi mobile memiliki peran penting bagi siswa, tidak sekedar alat komunikasi tetapi juga alat belajar dan mengakses perkembangan informasi dan juga akan mempengaruhi pendidikan dimasa depan [9][10].

Berdasarkan hasil observasi yang sudah dilakukan, salah satunya materi pembelajaran tentang jaringan organ tubuh manusia tidak bisa dipraktekkan secara langsung karena alat peraga yang memiliki harga yang cukup tinggi dan kurangnya waktu untuk kegiatan pembelajaran. Selama ini siswa hanya berfokus kepada guru saja dalam memahami materi materi sehingga tidak semua siswa dapat memahami materi dan ada sebagian siswa yang hanya belajar untuk sekedar formalitas saja di sekolah. Hal ini mungkin disebabkan karena kurang beragamnya media pembelajaran yang digunakan.

Media pembelajaran dapat membantu tugas seorang pendidik sebagai penyaji materi, selain itu juga bisa meningkatkan potensi belajar yang dapat membantu siswa dalam belajar [11]. Oleh sebab itu, perlu dikembangkan media pembelajaran yang kreatif yang bisa membuat siswa lebih tertarik untuk belajar. Beberapa alternatif media yang digunakan guru yang dimanfaatkan dalam pembelajaran materi organ tubuh manusia salah satunya adalah animasi Dua Dimensi (2D).

Animasi 2D berfokus pada pembuatan karakter, papan cerita, dan latar belakang di lingkungan 2D yang figurnya bisa bergerak naik turun, kiri, dan benar [12]. Komponen grafik 2D dapat dimanipulasi dengan transformasi geometris 
JURNAL ILMIAH KOMPUTER GRAFIS, Vol.13, No.2, Desember 2020, pp. 8-13

p-ISSN : 1979-0414(print)

e-ISSN : 2621-6256 (online)

http://journal.stekom.ac.id/index.php/pixel

2D [13]. Animasi 2D dilengkapi dengan video dan suara sehingga dapat memberi kemudahan siswa dalam memahami maksud dan tujuan materi yang diberikan [14]. Video animasi 2D dapat mempengaruhi semangat anak untuk terus belajar karena video animasi 2D banyak disukai anak.

\section{Metode Penelitian}

Dalam penelitian ini yang membuat sebuah animasi 2D ini adalah metode waterfall. Model ini menjelaskan tahap-tahap dalam pengembangan yang dimulai dari tahap pengumpulan data, analisis, desain, implementasi dan pengujian [15]. Proses pengembangan animasi 2D ini melewati beberapa tahapan dari mulai animasi itu direncanakan sampai dengan digunakan.

\subsection{Pengumpulan Data}

Tahap pertama dalam penelitian ini adalah pengumpulan data-data yang terkait untuk mengidentifikasi masalah dalam penelitian. Pengumpulan datanya meliputi studi literatur dan observasi.

1. Studi Literatur

Untuk mengembangkan perangkat lunak ini, penulis mencari literatur atau sumber pustaka yang berhubungan dengan animasi 2D media pembelajaran berbasis android. Literatur ini bisa berasal dari jurnal penelitian dan buku-buku.

\section{Observasi}

Mengadakan pengamatan langsung di lapangan, kemudian melakukan pencatatan secara sistematis terhadap objek serta mengamati keseluruhan aspek yang bersesuaian dengan kebutuhan pembuatan media pembelajaran.

\subsection{Analisis Kebutuhan}

Pada tahap ini dilakukan proses penggalian informasi kebutuhan perangkat lunak. Tahap analisa ini mengenai permasalahan media pembelajaran yang menyangkut kelebihan dan kekurangan dari animasi 2D media pembelajaran yang akan dibangun. Dan mempertimbangkan hardware dan software yang digunakan untuk melakukan penelitian ini..

\subsection{Desain (Perancangan)}

Dalam tahap desain, peneliti melakukan desain terhadap animasi 2D yang akan dibuat. Desain tersebut meliputi dari pembuatan Unified Modeling Language (UML), layout dari aplikasi, desain input dan output serta alur program dari setiap aksi yang ada ketika animasi tersebut dijalankan.

\subsection{Implementasi (Pengkodean)}

Pada tahap ini, semua desain yang sudah dirancang kemudian diimplementasikan dengan bantuan software Adobe Flash Professional CS6.
Setiap desain dibuat semenarik mungkin sehingga bisa manjadi daya tarik siswa untuk belajar. Selain itu juga ditambah dengan audio untuk menambah kenyamanan dalam penggunaan animasi ini. Setelah desain diimplementasi dan ditambah dengan audio, kemudian di export menjadi berbasis android.

\subsection{Pengujian Perangkat Lunak}

Sebelum animasi 2D ini didemokan ke siswa, maka tahap selanjutnya adalah pengujian. Tahap ini digunakan untuk mengetahui tingkat kesalahan dari animasi 2D yang udah dibuat. Hal itu dilakukan agar siswa bisa nyaman menggunakannya animasi ini tanpa harus ada terjadi error. Pengujian awal disini meliputi pengujian blackbox yang digunakan untuk mengetahui fungsi dari setiap menu sudah berfungsi dengan baik atau belum.

\section{HASIL DAN PEMBAHASAN}

Hasil dari penelitian ini adalah sebuah animasi 2D media pembelajaran jaringan organ tubuh manusia yang dapat diakses dari smartphone. Animasi 2D ini meliputi dari materi, gambar penyakit organ, video, tips, kuis dan profil pembuat. Selain itu animasi ini juga dilengkapi kuis yang berfungsi untuk mengetahui seberapa jauh siswa memahami setiap materi yang diberikan melalui animasi ini.

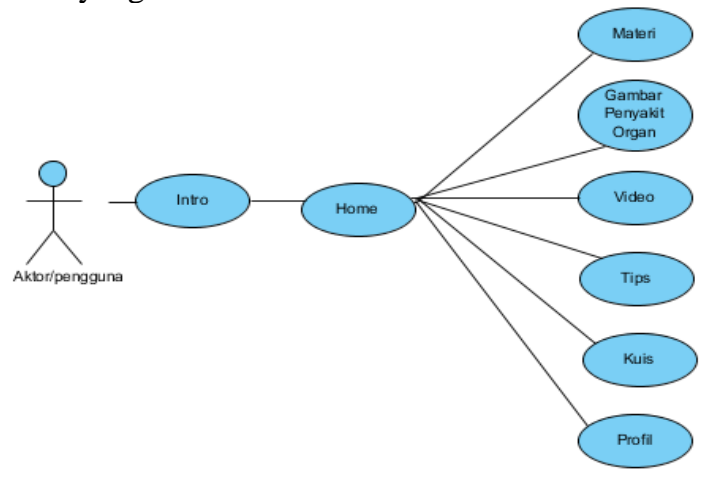

Gambar 1. Usecase Diagram Animasi 2D

Didalam animasi 2D media pembelajaran ini, definisi use case dijelaskan dalam dua sistem yaitu definisi diluar sistem dan didalam sistem.

Tabel 1. Definisi Usecase diluar sistem

\begin{tabular}{|c|c|lr|}
\hline No & Use Case & \multicolumn{2}{|c|}{ Deskripsi } \\
\hline 1. & User & $\begin{array}{l}\text { Pengguna yang menjalankan } \\
\text { animasi 2D r 2 } \\
\text { pembelajaran }\end{array}$ \\
\hline
\end{tabular}

Tabel 2. Definisi usecase didalam sistem

\begin{tabular}{|c|l|l|}
\hline No & Use Case & \multicolumn{1}{|c|}{ Deskripsi } \\
\hline 1. & Intro & $\begin{array}{l}\text { Fungsional sebagai halaman } \\
\text { intro media pembelajaran. }\end{array}$ \\
\hline 2. & Home & Fungsional sebagai halaman \\
\hline
\end{tabular}


JURNAL ILMIAH KOMPUTER GRAFIS, Vol.13, No.2, Desember 2020, pp. 8-13

p-ISSN : 1979-0414(print)

e-ISSN : 2621-6256 (online)

http://journal.stekom.ac.id/index.php/pixel

\begin{tabular}{|c|c|c|}
\hline & & $\begin{array}{l}\text { tempat memilih menu pilihan } \\
\text { yang disediakan. }\end{array}$ \\
\hline 3. & Materi & $\begin{array}{l}\text { Fungsional untuk memberi } \\
\text { info mengenai materi jaringan } \\
\text { organ tubuh manusia yang di } \\
\text { sediakan. }\end{array}$ \\
\hline 4. & $\begin{array}{l}\text { Gambar } \\
\text { Penyakit } \\
\text { Organ }\end{array}$ & $\begin{array}{l}\text { Fungsional untuk memberikan } \\
\text { beberapa gambar penyakit } \\
\text { pada jaringan organ tubuh } \\
\text { manusia beserta pencegahan, } \\
\text { dan sebab timbulnya penyakit } \\
\text { tersebut. }\end{array}$ \\
\hline 5 & Video & $\begin{array}{l}\text { Fungsional untuk memberi } \\
\text { info mengenai } \\
\text { terjadinya sistem respirasi, } \\
\text { sistem ekskresi, sistem } \\
\text { koordinasi, sistem reproduksi } \\
\text { dan sistem pertahanan tubuh } \\
\text { melalui media berbentuk } \\
\text { video animasi. }\end{array}$ \\
\hline 6. & Tips & $\begin{array}{l}\text { Fungsional untuk memberikan } \\
\text { tips hidup sehat pada organ } \\
\text { tubuh beserta jam piket organ } \\
\text { tubuh manusia. }\end{array}$ \\
\hline 7. & Kuis & $\begin{array}{l}\text { Fungsional sebagai kuis } \\
\text { dalam pembelajaran. }\end{array}$ \\
\hline 8. & Profil & $\begin{array}{l}\text { Fungsional seabgai halaman } \\
\text { informasi pembuat animasi } \\
\text { 2D }\end{array}$ \\
\hline
\end{tabular}

Materi yang dibahas dalam animasi 2D media pembelajaran ini mengenai pembelajaran penyusun jaringan organ tubuh manusia, yang berisi materi sistem respirasi, sistem ekskresi, sistem koordinasi, sistem reproduksi dan pertahanan tubuh. Dalam setiap materi tersebut terbagi atas bagian organ-organ dalamnya. Respirasi terdiri atas hidung, tekak dan tenggorokan, ekskresi terdiri atas ginjal, hati, kulit dan paru-paru, Koordinasi terdiri atas saraf, endoktrin, dan indra, Reproduksi terdiri dari pria dan wanita, pertahanan tubuh terdiri dari nonspesifik dan spesifik. Di dalam materi organ terdapat juga struktur organ dan penjelasannya

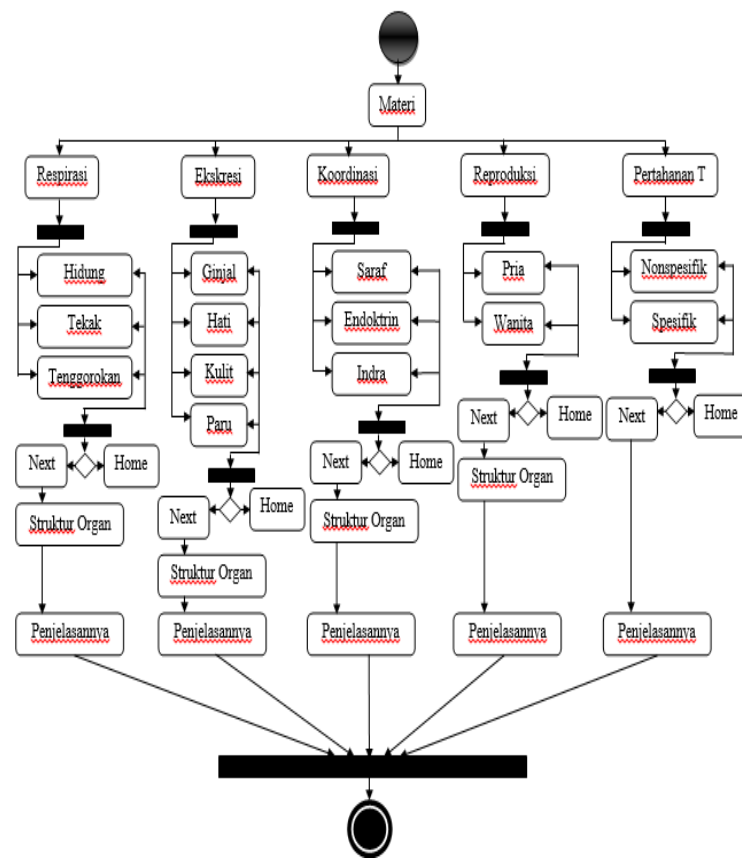

Gambar 2. Activity Diagram Materi

Tahapan selanjutnya yaitu tahapan implementasi. Dalam tahapan ini, animasi dibuat dengan menggunakan software Adobe Flash Professional CS6 kemudian di export menjadi berbasis android. Animasi didesain dengan gambar yang menarik dan warna yang cerah sehingga bisa menarik minat belajar siswa yang menggunakannya.

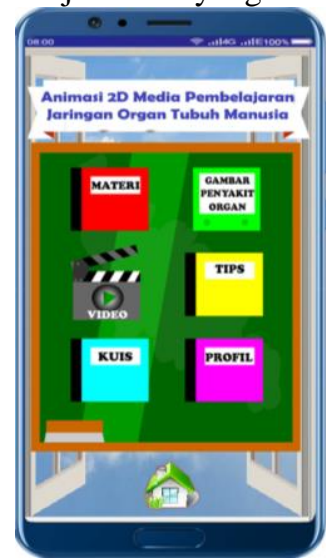

Gambar 3. Menu utama animasi 2D

Ketika user menjalankan icon animasi 2D yang sebelumnya sudah diinstal di smarphone mereka, maka akan muncul halaman awal dari animasi. Didalam halaman awal tersebut terdapat beberapa menu yang meliputi menu materi, menu video, menu penyakit organ, menu tips, menu kuis dan menu profil. 
JURNAL ILMIAH KOMPUTER GRAFIS, Vol.13, No.2, Desember 2020, pp. 8-13

p-ISSN : 1979-0414(print)

e-ISSN : 2621-6256 (online)

http://journal.stekom.ac.id/index.php/pixel

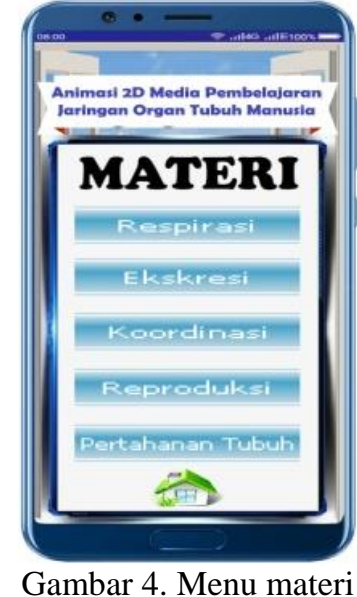

Pada menu materi terdapat beberapa materi yang dibahas yang meliputi materi respirasi, materi ekskresi, materi koordinasi, materi reproduksi dan materi pertahanan tubuh. Dalam setiap materi terdapat beberapa animasi 2D yang berisi penjelasan singkat tentang pengertian,fungsi dan struktur organ dari setiap sub materi.

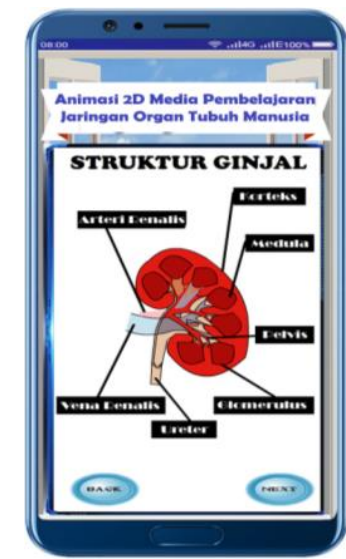

Gambar 5. Penjelasan materi

Selanjutnya didalam media pembelajarn ini, juga terdapat menu video animasi 2D yang menjelaskan dari jaringan organ manusia. Didalam menu video terdapat beberapa video yang disediakan. Video animasi tersebut menjelaskan tentang proses dari kegiatan yang dilakukan organ tubuh manusia. Terdapat gambar animasi 2D beserta keterangan dari setiap gambar yang dibungkus seacara menarik. Selain itu video ini juga disertasi suara dan backsound untuk penjelasan dari setiap video.
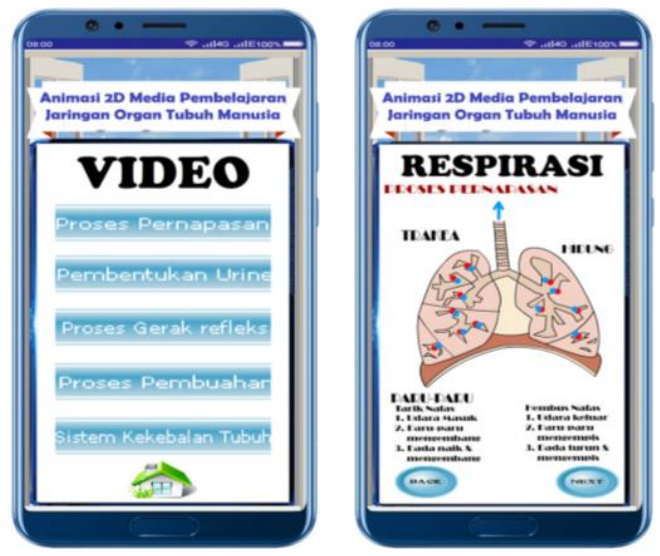

Gambar 6. Menu video

Selain menu materi dan video, animasi 2D media pembelajaran ini dilengkapi dengan menu kuis yang digunakan untuk memberikan soal atau latihan kepada siswa terhadapt materi yang diberikan. Setiap materi memiliki soal yang berbeda beda yang akan keluar secara random sehingga pertanyaan antara siswa satu dengan yang siswa lain tidak sama. Soal kuisnya berupa soal pilhan ganda yang terdiri dari 10 soal yang harus dijawab oleh siswa.
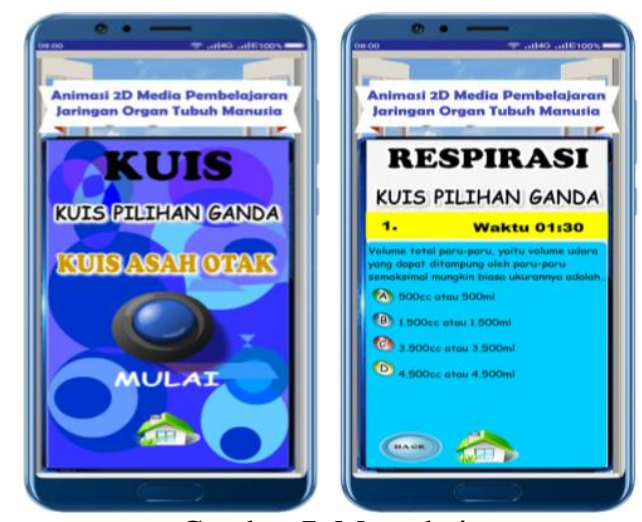

Gambar 7. Menu kuis

Tahapan terakhir yaitu pengujian yang lebih difokuskan pada syarat fungsional pada sistem. Pengujian ini digunakan untuk menghasilkan analisa yang nantinya diperlukan untuk mengerjakan seluruh keperluan fungsional program. Pengujian ini berfungsi untuk menemukan kesalahan yang terjadi pada sistem sehingga diharapkan dapat menghasilkan sistem yang bebas dari kesalahan. Pada animasi 2D media pembelajaran ini pengujian dengan metode blackbox yang bertujuan untuk mengetahui tingkat kesalahan dari aplikasi sebelum diujicobakan ke siswa.

Tabel 3. Pengujian blackbox 
JURNAL ILMIAH KOMPUTER GRAFIS, Vol.13, No.2, Desember 2020, pp. 8-13

p-ISSN : 1979-0414(print)

e-ISSN : 2621-6256 (online)

http://journal.stekom.ac.id/index.php/pixel

\begin{tabular}{|c|c|c|c|}
\hline Pengujian & Bentuk Pengujian & Hasil yang diharapkan & Hasil Uji \\
\hline $\begin{array}{l}\text { Pengujian } \\
\text { animasi 2D apk }\end{array}$ & $\begin{array}{l}\text { Mengklik icon } \\
\text { animasi 2D pada } \\
\text { smartphone }\end{array}$ & $\begin{array}{l}\text { Muncul tampilan } \\
\text { halaman awal animasi } 2 \mathrm{D} \\
\text { media pembelajaran } \\
\text { organ tubuh manusia }\end{array}$ & $\begin{array}{l}\mathrm{X}] \text { Diterims } \\
{\left[\begin{array}{l}\text { [ } \\
\text { [ Ditolak }\end{array}\right.}\end{array}$ \\
\hline $\begin{array}{l}\text { Pengujian menu } \\
\text { materi }\end{array}$ & $\begin{array}{l}\text { Mengklik menu } \\
\text { materi }\end{array}$ & $\begin{array}{l}\text { Muncul halaman menu } \\
\text { materi }\end{array}$ & $\begin{array}{l}\mathrm{X}] \text { Diterims } \\
{[\text { ] Ditolak }}\end{array}$ \\
\hline $\begin{array}{l}\text { Pengujian salah } \\
\text { satu materi }\end{array}$ & $\begin{array}{l}\text { Mengklik salah satu } \\
\text { materi }\end{array}$ & $\begin{array}{l}\text { Muncul materi yang } \\
\text { dipilih besenta penjelasan } \\
\text { dan fungsinya }\end{array}$ & $\begin{array}{l}\mid \mathrm{X}] \text { Diterims } \\
{\left[\begin{array}{l}\text { [ } \\
\text { [ Ditolak }\end{array}\right.}\end{array}$ \\
\hline $\begin{array}{l}\text { Pengujian menu } \\
\text { video }\end{array}$ & $\begin{array}{l}\text { Mengklik menu } \\
\text { video }\end{array}$ & $\begin{array}{l}\text { Muncul halaman menu } \\
\text { video }\end{array}$ & 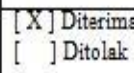 \\
\hline $\begin{array}{l}\text { Pengujian salah } \\
\text { satu video }\end{array}$ & $\begin{array}{l}\text { Mengklik s slahs sath } \\
\text { video }\end{array}$ & $\begin{array}{l}\text { Muncul video yang } \\
\text { dipilih yang berupa } \\
\text { animasi2D beserta suara } \\
\text { dan backsoundnya }\end{array}$ & 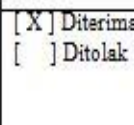 \\
\hline $\begin{array}{l}\text { Pengujian menu } \\
\text { penyakit organ }\end{array}$ & $\begin{array}{l}\text { Menghliti menu } \\
\text { penyakit organ }\end{array}$ & $\begin{array}{l}\text { Muncul halaman menu } \\
\text { penyakit organ tubuh } \\
\text { manusia }\end{array}$ & $\begin{array}{l}\mathrm{X}] \text { Diterims } \\
{\left[\begin{array}{l}\text { [ } \\
\text { [ Ditolak }\end{array}\right.}\end{array}$ \\
\hline $\begin{array}{l}\text { Pengujian salah } \\
\text { satu penyakit } \\
\text { organ }\end{array}$ & $\begin{array}{l}\text { Mengklik salah sath } \\
\text { penyakit organ }\end{array}$ & $\begin{array}{l}\text { Muncul penyakit organ } \\
\text { tubuh manusia yang } \\
\text { dipilih beserta penjelasan } \\
\text { dan keterangannya }\end{array}$ & 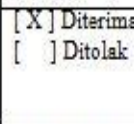 \\
\hline $\begin{array}{l}\text { Pengujian menu } \\
\text { tips }\end{array}$ & Menghlik menu tips & $\begin{array}{l}\text { Muncul halaman menu } \\
\text { tips }\end{array}$ & $\begin{array}{l}\text { X] Diterims } \\
{[\text { ] Ditolak }}\end{array}$ \\
\hline $\begin{array}{l}\text { Pengujian menu } \\
\text { kuis }\end{array}$ & $\begin{array}{l}\text { Mengklik menu } \\
\text { kuis }\end{array}$ & $\begin{array}{l}\text { Muncul halaman menu } \\
\text { kuis }\end{array}$ & 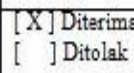 \\
\hline $\begin{array}{l}\text { Pengujian salah } \\
\text { satu kuis }\end{array}$ & $\begin{array}{l}\text { Mengklik salah satur } \\
\text { kuis }\end{array}$ & $\begin{array}{l}\text { Muncul soal yang berisi } \\
\text { pilihan ganda dari materi } \\
\text { yang dipilih }\end{array}$ & 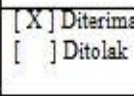 \\
\hline
\end{tabular}

\section{KESIMPULAN}

Berdasarkan hasil penelitian, animasi 2D media pembelajaran ini membuat siswa lebih cepat mengerti dalam memahami materi organ tubuh manusia yang biasanya hanya belajar dari buku saja. Secara umum tampilan dari animasi media belajar ini terbagi menjadi enam halaman yaitu halaman materi, halaman gambar penyakit organ, halaman video, halaman tips, halaman kuis dan halaman profil. Animasi ini memiliki beberapa unsur seperti teks, audio, video dan gambar animasi sehingga lebih menarik perhatian siswa merasa senang dalam belajar.

\section{DAFTAR PUSTAKa}

[1] S. Muyaroah and M. Fajartia, "Pengembangan Media Pembelajaran Berbasis Android dengan menggunakan Aplikasi Adobe Flash CS 6 pada Mata Pelajaran Biologi," Innov. J. Curric. Educ. Technol., vol. 6, no. 2, pp. 22-26, 2017.

[2] S. A, "Pembelajaran Biologi Pokok Bahasan Sistem Pernapasan Pada Manusia Melalui Media Gambar di MTSN Jongar Kabupaten Aceh Tenggara," J. Biot., vol. 4, no. 2, p. 147, 2016.

[3] N. B. Nugraha, A. Sellyana, and M. Suhaidi, "Pelatihan E-Learning Pada Guru SMA IT Plus Bazma Brilliant,” vol. 2, no. 2, pp. 127-

132, 2019.

A. Fattah and R. Setyadi, "Pengembangan Media Pembelajaran Berbasis Android pada Mata Pelajaran Pengenalan Microsoft Word di LPK SHEZA Pontianak," J. Teknol. Inf. dan Pendidik., vol. 12, no. 2, pp. 1-7, 2019.

H. Wahyuni, "Pengembangan Bahan Ajar Berbasis Android Untuk," CESS (Journal Comput. Eng. Syst. Sci., vol. 3, no. 1, pp. 8386, 2018.

U. N. Labibah, I. Wilujeng, S. Sulaiman, and L. Rahmawati, "Android-Based Physics Learning Media Integrated Landslide Disaster," J. Ilm. Pendidik. Fis. Al-Biruni, vol. 8, no. 2, pp. 229-236, 2019.

M. Saefi, B. Lukiati, and E. Suarsini, "Developing Android-Based Mobile Learning On Cell Structure And Functions Lesson Subject Topic To Optimize Grade XI Students' Cognitive Comprehension," J. Pendidik. Sains, vol. 19, no. 2, pp. 57-63, 2017.

[8] A. D. Sutiasih and R. P. Saputri, "Pengembangan mobile learning berbasis android sebagai media pembelajaran organisasi arsitektur komputer," J. Inov. Teknol. Pendidik., vol. 6, no. 2, pp. 137-147, 2019.

[9] A. R. Asmi, A. Novemy, D. Surbakti, and Y. Hasan, "Pengembangan Model Mobile Learning Berbasis Aplikasi Android pada," vol. 5, no. 1, pp. 30-40, 2019.

[10] D. M. Pahlifi and M. Fatharani, "Androidbased learning media on human respiratory system material for high school students," $J$. Inov. Pendidik. IPA, vol. 5, no. 1, pp. 109116, 2019.

[11] R. Agustien, N. Umamah, and S. Sumarno, "Pengembangan Media Pembelajaran Video Animasi Dua Dimensi Situs Pekauman di Bondowoso Dengan Model Addie Mata Pelajaran Sejarah Kelas X IPS," J. Edukasi, vol. 5, no. 1, p. 19, 2018.

[12] M. H. F. M. Kamil, I. S. Z. Abidin, and F. F. Osman, "Design process: 2D interactive video animation development for cosmetic awareness among women," J. Crit. Rev., vol. 7, no. 8, pp. 891-894, 2020.

[13] S. M. H. Asraf and S. Z. S. Idrus, "Hybrid Animation: Implementation of TwoDimensional (2D) Animation," J. Phys. Conf. Ser., vol. 1529, no. 2, 2020.

[14] R. S. Untari, W. Kamdi, A. Dardiri, S. Hadi, and D. Nurhadi, "The development and application of interactive multimedia in project-based learning to enhance students' achievement for 2D animation making," Int. J. Emerg. Technol. Learn., vol. 15, no. 16, 
JURNAL ILMIAH KOMPUTER GRAFIS, Vol.13, No.2, Desember 2020, pp. 8-13

p-ISSN : 1979-0414(print)

e-ISSN : 2621-6256 (online)

http://journal.stekom.ac.id/index.php/pixel

pp. 17-30, 2020.

[15] M. A.S, Rosa; Shalahuddin, Rekayasa

Berorientasi Objek. Bandung: Informatika Perangkat Lunak Terstruktur dan 